\title{
Veertig jaar harm reduction in Nederland: geen schaamte, maar trots!
}

\author{
Anouk de Gee · Daan van der Gouwe
}

Published online: 23 January 2020

(C) The Author(s) 2020

Samenvatting Ruim veertig jaar is harm reduction een belangrijke pijler van het Nederlandse drugsbeleid. In die tijd is er veel veranderd. Probleemgebruikers van heroïne en basecoke zijn grotendeels uit het straatbeeld verdwenen, 'nieuwe' middelen en doelgroepen dienden zich aan, en de politieke en maatschappelijk aandacht voor harm reduction verslapte. Waar enerzijds gebruik van drugs onder specifieke groepen genormaliseerd lijkt, wordt er anderzijds ook steeds meer met het vingertje naar drugsgebruikers gewezen, bijvoorbeeld door politici en politie. Wat betekenen deze ontwikkelingen voor de positie van harm reduction in Nederland en hoe ziet de toekomst eruit? Het Netwerk Harm Reduction zocht het uit.

\section{Harm reduction: geboren en. .. vergeten?}

'Ik denk dat een drugsvrije samenleving een illusie is, en als je daar als overheid desondanks toch naar streeft is dat schadelijk uit het oogpunt van de bescherming van de volksgezondheid' [1]. Deze visie van Eddy Engelsman - van 1976-1992 topambtenaar van het ministerie van Welzijn, Volksgezondheid en Cultuur (het huidige ministerie van VWS) - heeft een belangrijke bijdrage geleverd aan de totstandkoming van het spraakmakende Nederlandse drugsbeleid dat vandaag de dag nog grotendeels overeind staat. Een drugsbeleid gestoeld op pragmatisme, met als centrale doelstelling 'de preventie en beheersing van uit drugsgebruik voortvloeiende gemeenschaps- en individuele risico's' [2]. Het volksgezondheidsbelang werd geprioriteerd boven het bestraffen van wetsovertredingen en pogingen om drugs uit de samenleving te verbannen.

A. de Gee · D. van der Gouwe $(\bowtie)$

Trimbos-instituut, Utrecht, Nederland

dgouwe@trimbos.nl
Harm reduction is sindsdien een belangrijke pijler van het Nederlandse drugsbeleid.

De oorsprong van harm reduction in Nederland ligt in verschillende initiatieven die in de jaren tachtig en negentig van de vorige eeuw zijn ontstaan vanuit het maatschappelijk middenveld, gebruikersbewegingen en later ook de reguliere hulpverlening en overheid. Het was een reactie op de destijds zichtbaar aanwezige drugsproblematiek in veel grote en middelgrote steden. De situatie van problematische harddruggebruikers verbeterde in de periode daarop dusdanig dat de politieke en maatschappelijke aandacht voor harm reduction langzaam afnam. Tegenwoordig gaat het publieke debat over het normaliseren van drugsgebruik, de (mede)verantwoordelijkheid van drugsgebruikers voor drugscriminaliteit en milieuschade, en zelfs een hardere aanpak van drugsgebruikers zelf (getuige het in 2019 afgekondigde zerotolerancebeleid tijdens het Amsterdam Dance Event). Er lijkt een repressievere wind te waaien, waarbij de wens om drugs(gebruik) helemaal te verbannen steeds meer bijval krijgt.

\section{Antwoorden op prangende vragen}

Wat betekent bovenstaande verschuiving in het drugsdebat voor het aanbod van en vraag naar harm reduction-voorzieningen in Nederland? Wat is de huidige positie van harm reduction in het beleids- en zorglandschap, en hoe ziet de toekomst eruit? Om antwoorden op deze vragen te krijgen, heeft het Netwerk Harm Reduction (https://www.netwerkihr.nl/) voorheen Netwerk Infectieziekten \& Harm Reduction - in 2019 totaal 27 harm reduction-werkers, beleidsmakers, onderzoekers en belangenbehartigers geïnterviewd. We beschrijven hier enkele interessante inzichten die uit de interviews naar voren kwamen. 


\section{Wat is harm reduction?}

Elk interview startte met de vraag 'Wat versta je onder harm reduction?' Volgens alle geïnterviewden betrof harm reduction (veel onderlinge verschillen in accenten en nuances daargelaten) het terugdringen van (gezondheids)schade door het gebruik van drugs. In eerste instantie voor de gebruiker zelf, maar - door een aantal geïnterviewden expliciet genoemd - ook voor diens omgeving en de samenleving als geheel. Dit komt overeen met de definitie van harm reduction van het European Monitoring Centre for Drugs and Drug Addiction: 'Harm reduction encompasses interventions, programmes and policies that seek to reduce the health, social and economic harms of drug use to individuals, communities and societies' [3].

Bij harm reduction denkt men al snel aan concrete voorzieningen, zoals spuitomruil, methadonverstrekking of gebruiksruimten. Aan deze voorzieningen liggen principes ten grondslag, die ook in de interviews ter sprake kwamen, namelijk 1) acceptatie van het gebruik, minderen of stoppen van het gebruik is geen voorwaarde voor hulp of ondersteuning; 2) niet-moraliserend: harm reduction is een pragmatische aanpak waarbij drugsgebruik niet veroordeeld wordt; 3) gebaseerd op evidentie; en 4) laagdrempelig en toegankelijk, door gebruikers zelf actief te betrekken.

Van oorsprong heeft harm reduction vooral betrekking op het voorkomen dan wel beperken van schade bij probleemgebruik, zoals verslaving. De geïnterviewden geven daarnaast ook aan dat verslaving geen voorwaarde hoeft te zijn voor harm reduction, net zomin als dat ze zich hoeft te beperken tot illegale middelen. Ook bij recreatief gebruik, binnen uiteenlopende doelgroepen (bijvoorbeeld chemseks of gebruik van prestatieverhogende middelen in de sportschool) en bij legale middelen (tabak of alcohol) kan harm reduction goed worden toegepast bij beleid en interventies.

\section{Preventie of harm reduction?}

Met de opkomst van de dancecultuur in de jaren tachtig en het gebruik van drugs in deze settings deden ook hier schadebeperkende interventies hun intrede. Voorbeelden hiervan zijn de drugstestservices, peerprojecten (voorlichting), aanwezigheid van een EHBO-dienst of het verplicht stellen van gratis waterpunten op feesten. Opvallend is dat bij recreatief gebruik, in tegenstelling tot harm reduction bij probleemgebruik, en bij legale middelen meestal de noemer 'preventie' gebruikt wordt. Dit geldt zowel richting de doelgroepen waar deze activiteiten zich op richten en die zich door de associatie met 'de heroïnejunk' mogelijk niet aangesproken voelen met de term 'harm reduction', als richting de maatschappij en de (inter)nationale politiek, om niet de indruk te wekken dat drugsgebruik actief wordt toegestaan of aangemoedigd. De geïnterviewden verschilden van mening over wanneer harm reduction en wanneer preventie als term het meest geschikt/gewenst was om te gebruiken. Geconcludeerd kan worden dat de uitwerking in maatregelen, interventies en benamingen bij recreatief gebruik en legale middelen anders kan zijn dan bij probleemgebruik. Maar omdat de onderliggende principes hetzelfde zijn kan dit - ongeacht de gehanteerde terminologie - ook als harm reduction gezien worden. Dit geldt ook voor beleid en interventies gericht op andere doelgroepen, zoals chemseks en sporters die prestatieverhogende middelen gebruiken, die aansluiten bij het gedachtegoed van harm reduction.

\section{De verworvenheden van 'klassieke' harm reduction: trots en zorgen}

Aanvankelijk had harm reduction vooral betrekking op probleemgebruikers, die harddrugs injecteerden en/of rookten via folie of pijpje. In Nederland behoren veel harm reduction-voorzieningen voor deze doelgroep, inclusief de behandeling met medische heroïne, inmiddels tot het reguliere zorgaanbod. Hier mogen we volgens de geïnterviewden trots op zijn. Als gevolg daarvan zijn de leefomstandigheden, de gezondheid en kwaliteit van leven van drugsgebruikers sterk verbeterd, en zijn drugsoverlast en verwervingscriminaliteit aanzienlijk afgenomen [4, 5]. Desondanks zijn vertegenwoordigers van het Nederlandse drugsbeleid behoorlijk terughoudend in het uitdragen van deze resultaten, zowel nationaal als internationaal. Dat is zonde én onterecht, zo vonden meerdere geïnterviewden. De positieve opbrengsten van meer dan dertig jaar harm reduction - ook bij recreatieve gebruikers - verdienen het om goed in kaart gebracht en breed uitgedragen te worden.

De inbedding van harm reduction-voorzieningen binnen de reguliere hulpverlening heeft ook een keerzijde. Veel mensen die werkzaam zijn in harm reduction-voorzieningen weten wel wát ze doen, maar veelal niet waaróm - de filosofie van het harm reduction-gedachtegoed. Zij hebben de tijd waarin harm reduction opkwam niet meegemaakt. Waardevolle kennis dreigt verloren te gaan omdat harm reduction-pioniers het actieve werkveld verlaten zonder hun ervaring en kennis voldoende over te dragen. In vergelijking met vroeger en ook vergeleken met het buitenland wordt in Nederland heden ten dage volgens verschillende geïnterviewden geen noodzaak (meer) gevoeld om voor harm reduction te blijven vechten, ook niet in het publieke en maatschappelijke debat.

Verschillende geïnterviewden missen het actief betrekken van gebruikers bij relevante besluitvorming en de vormgeving van harm reduction-interventies en -voorzieningen. Dat geldt expliciet ook wanneer het gaat om zicht te krijgen en houden op de omvang en vraag vanuit de doelgroep, inclusief groepen die nu nog onvoldoende in beeld zijn. De behoeften 
van gebruikers lijken minder centraal te staan dan vroeger. In het geprotocolleerd en evidence-based werken wordt nogal eens vergeten ook processen in te bouwen om structureel naar de doelgroep te blijven luisteren.

\section{Harm reduction is kwetsbaar}

Harm reduction heeft behalve op specifieke zienswijzen en voorzieningen ook betrekking op beleid en wetgeving. Verschillende geïnterviewden wijzen ook op de recente verschuiving in het politieke debat naar een meer moraliserend en conservatief klimaat. Nederland was jarenlang pionier op het gebied van harm reduction. Dat tij is gekeerd. 'We zijn allang geen gidsland meer.' Het politieke klimaat is dominanter geworden en de geïnterviewden missen het initiatief vanuit de overheid om harm reduction op de agenda te houden en uit te dragen als een waardevol onderdeel van ons drugsbeleid. Hoewel enerzijds harm reduction nog altijd door het Ministerie van Volksgezondheid, Welzijn en Sport wordt ondersteund, klinkt anderzijds een steeds luidere stem van het Ministerie van Veiligheid en Justitie, dat elk gebruik van drugs sterk veroordeelt. Gedachtegoed dat ten grondslag ligt aan de zinloze 'war on drugs' lijkt meer ruimte te krijgen, soms ten koste van de gezondheidsbenadering waarbij acceptatie van gebruik essentieel is. Dat maakt - in combinatie met het verdwijnen van de kennis over de principes en het nauwelijks uitdragen van de verworvenheden - dat harm reduction in het huidige politieke klimaat kwetsbaar is.

De verharding van het drugsdebat heeft mogelijk ook effect op de verslavingszorg. Sommige geïnterviewden signaleren een verstarring en sterkere nadruk op abstinentie van alle middelen, inclusief tabak, wat voor sommige cliënten een extra drempel kan opwerpen. Daarnaast geeft een aantal geïnterviewden aan dat de harde toon stigmatisering van drugsgebruikers in de hand kan werken, iets wat harm reduction nu juist tracht te voorkomen. Stigmatisering vormt immers een belangrijke barrière voor de gebruiker om hulp te zoeken [6].

\section{Tijd voor actie}

De meeste geïnterviewden zijn van mening dat harm reduction-voorzieningen en de financiering daarvan zullen blijven bestaan. Toch is er alle reden om als voorstanders van harm reduction en professionals die daarin werkzaam zijn niet stil te blijven zitten. Veranderingen in de drugsgebruikende populatie, de populariteit van verschillende drugs, en in de publieke en politieke opinie rondom drugs(gebruik) vragen om een actieve en innoverende houding. Nieuwe vraagstukken blijven zich aandienen, zoals het injecteren van methamfetamine en andere middelen door specifieke doelgroepen, signalen over de toename van het aantal men- sen dat afhankelijk is van zware pijnstillers (zoals fentanyl en oxycodon), of de manier waarop 'klassieke' harm reduction-voorzieningen kunnen inspelen op een kleiner en ouder wordende groep heroïnegebruikers. Het huidige landschap kent bedreigingen, zoals het veranderende politieke klimaat, maar zeker ook kansen, zoals het nieuwe paradigma van herstelgericht werken in de zorg. De geïnterviewden geven aan dat harm reduction en herstel complementair zijn aan elkaar. Harm reduction kan een waardevolle bijdrage leveren aan of zelfs noodzakelijk zijn voor herstel.

Gepaste trots op wat is bereikt, is op zijn plaats - dat mag best worden uitgedragen. En met de opbrengsten en het gedachtegoed van harm reduction mag een positieve bijdrage worden geleverd aan het huidige debat. Om dat te kunnen doen is het van groot belang de huidige stand van zaken van harm reduction in Nederland te onderzoeken. Daarom inventariseert het Harm Reduction Netwerk in 2020 het huidige aanbod van harm reduction-voorzieningen in Nederland. Daarnaast roept het Netwerk Harm Reduction sympathisanten en professionals werkzaam in harm reduction op initiatieven te ontplooien om elkaar te blijven inspireren, gezamenlijk het gedachtegoed uit te dragen en het collectieve geheugen te bewaken.

Open Access This article is licensed under a Creative Commons Attribution 4.0 International License, which permits use, sharing, adaptation, distribution and reproduction in any medium or format, as long as you give appropriate credit to the original author(s) and the source, provide a link to the Creative Commons licence, and indicate if changes were made. The images or other third party material in this article are included in the article's Creative Commons licence, unless indicated otherwise in a credit line to the material. If material is not included in the article's Creative Commons licence and your intended use is not permitted by statutory regulation or exceeds the permitted use, you will need to obtain permission directly from the copyright holder. To view a copy of this licence, visit http://creativecommons.org/licenses/by/4.0/.

\section{Literatuur}

1. Marijnissen H. Het dogma voorbij. Trouw. 20 Juli 2002.

2. T.K. 24077-3. Tweede Kamer der Staten-Generaal vergaderjaar 1994-1995, publicatienummer 24077 nr. 3. Drugbeleid; Nota 'Het Nederlandse drugbeleid: continuïteit en verandering'. Den Haag: SDU uitgevers; 1995.

3. European Monitoring Centrefor Drugs andDrugAddiction. Harm reduction topics page. 2019. http://www.emcdda. europa.eu/topics/harm-reduction. Geraadpleegd op 16 november 2019.

4. Laar M van, Ooyen-Houben M van. Evaluatie van het Nederlandse drugsbeleid. Utrecht: Trimbos instituut/ WODC; 2009.

5. BielemanB, BiesmaS, SnippeJ, BeelenA.Drugsgerelateerde overlast. Groningen-Rotterdam: Intraval; 2009.

6. United Nations Office on Drugs and Crime, World Health Organization. International Standards for the Treatment of Drug Use Disorders. Vienna: UNODC, WHO;2017. 